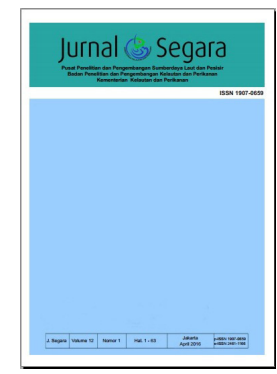

JURNAL SEGARA

http://ejournal-balitbang.kkp.go.id/index.php/segara

ISSN : 1907-0659

e-ISSN : 2461-1166

Nomor Akreditasi: 766/AU3/P2MI-LIPI/10/2016

\title{
MODEL NUMERIK LINTASAN SEBARAN LARVA KARANG DI KANDIDAT LOKASI PENEMPATAN BEKAS STRUKTUR ANJUNGAN MIGAS LEPAS PANTAI (RIG TO REEF)
}

\section{MODEL NUMERIK LINTASAN SEBARAN LARVA KARANG \\ DI KANDIDAT LOKASI PENEMPATAN BEKAS STRUKTUR ANJUNGAN MIGAS LEPAS PANTAI (RIG TO REEF)}

\author{
R. Bambang A Nugraha1), Heron Surbakti'2), Agustin Rustam ${ }^{1)}$
}

\author{
1)Pusat Riset Kelautan, BRSDMKP-KKP \\ Jl. Pasir Putih 1 Ancol Timur, Jakarta Utara 14430 \\ ${ }^{2}$ Fakultas IImu Kelautan, Universitas Sriwijaya \\ Jalan Srijaya Negara, Bukit Besar, llir Barat I, Bukit Lama, llir Bar. I, Kota Palembang, Sumatera Selatan 30128
}

Diterima: 7 Januari 2019; Diterima Setelah Perbaikan: 6 November 2020; Disetujui Terbit: 20 November 2020

\begin{abstract}
ABSTRAK
Anjungan migas lepas pantai yang sudah dibongkar ketika telah memasuki masa akhir produksinya dapat dimanfaatkan sebagai terumbu karang buatan (artificial reef). Program ini di beberapa negara dikenal dengan sebutan Rigs-to-Reef (R2R). Salah satu faktor penting yang harus dipertimbangkan dalam penempatan struktur Rigs untuk terumbu buatan ini adalah konektivitas antara habitat asli sebagai sumber larva karang dan kandidat lokasi agar larva karang dapat menyebar, tumbuh dan berkembang dengan baik. Faktor penting yang mempengaruhi planulasi (pelepasan dan penyebaran larva karang ke laut sekitar) adalah sirkulasi arus laut di lapisan permukaan. Penelitian ini bertujuan untuk membuat simulasi sebaran larva karang dan memetakan pola konektivitas antara kawasan konservasi Perairan Daerah (KKPD) Bontang (source) dan lokasi baru untuk penempatan struktur Rigs (sink). Sebaran larva karang diperoleh dengan menggunakan pemodelan biofisik untuk mendapatkan skenario rekruitmen dan jejak penyebaran larva. Pemodelan biofisik digunakan sebagai alat prediksi penyebaran larva untuk menilai konektivitas antar kawasan konservasi dan untuk evaluasi umum dari berbagai faktor yang berperan dalam pergerakan larva. Simulasi sebaran larva dibuat dengan menggunakan modul Agent Based Modelling (Passive Drifter) menggunakan MIKE 21 FM untuk memprediksi sebaran larva karang di kandidat lokasi. Simulasi sebaran larva dilakukan di beberapa bulan yang mewakili puncak 4 musim yang berbeda, yakni musim barat (bulan Januari), musim Peralihan I (Mei), musim Timur (Agustus) dan musim Peralihan II (Oktober). Hasil dari model sebaran larva mengindikasikan bahwa proses penyebaran larva karang di kawasan konservasi Bontang dipengaruhi oleh arus permukaan yang dibangkitkan oleh pasang surut serta variasi angin musiman dan menyebar dengan baik ke kandidat lokasi R2R.
\end{abstract}

Keywords: Model Numerik, lintasan sebaran larva karang, lokasi bekas struktur anjungan migas lepas pantai, Rig to reef (R2R), Agent Based Modelling (ABM), Mike 21 FM

\section{ABSTRACT}

The abandoned offshore oil and gas platforms that have reached their end production can be utilized as artificial reef. The converting obsolete Rig structures for reefing area is also known as Rigs-to-Reef (R2R). One of the important factors that should be considered in the placement of those Rig structures is the connectivity between native habitats as coral larvae source and downstream habitat where the coral larvae will spread, sink, grow and well developed. An important factor influencing the planula (release and dispersal of coral larvae to the surrounding sea) is the circulation of ocean currents. This study aims to simulate the distribution of coral larvae and map the connectivity pattern between the Bontang's protected area (KKPD) and the new location. The biophysical model was used to predict the distribution of coral larvae and find various factors

Corresponding author:

Jl. Pasir Putih I Ancol Timur, Jakarta Utara 14430. Email: bambang.nugraha@kkp.go.id 


\begin{abstract}
from within the movement of larvae. The simulation of larval distribution was made by using Agent Based Modeling module (Drifter) using MIKE 21 FM, to predict the distribution of coral larvae in the location candidate. Simulation of larval distribution was done on 4 different seasons, ie wind season (January), transition season I (May), season East (August) and Transition II (October). The results of the larval distribution model indicate that the process of spreading coral larvae in the Bontang conservation area is influenced by surface currents generated by tides and seasonal wind variations and spreads well to candidate location of $R 2 R$.
\end{abstract}

\title{
Keywords: Coral planula, Rig to reef (R2R), Bontang Marine Protected Area, Agent BAed Modelling, MIKE 21 FM.
}

\section{PENDAHULUAN}

Decommissioning atau dismantle di dunia eksplorasi migas merupakan upaya penutupan dan pembongkaran fasilitas produksi pada anjungan migas lepas pantai ketika usaha ekstraksi migas tersebut telah memasuki masa akhir produksi dan tidak menguntungkan lagi secara ekonomi. Tujuannya adalah mengembalikan kondisi lingkungan sekitar pengeboran ke kondisi semula sebelum adanya kegiatan ekstraksi tersebut (Bemment, 2001). Saat ini ada trend di beberapa negara seperti USA (negara bagian Louisiana, Mississippi dan Texas), Australia, Malaysia dan Brunai Darussaalam untuk mengkonversi struktur raksaksa tersebut menjadi beberapa alternatif pemanfaatan seperti stasiun pengamatan lingkungan laut dan atmosfer (research station), energy baru terbarukan dari angin dan laut (wind and ocean energy), budidaya lepas pantai (offshore aquaculture), pariwisata (dive spot dan hotel) dan terumbu karang buatan (artificial reef) (Kolian \& Sammarco, 2005; Jagerroos \& Krause, 2016).

Adanya sejumlah pilihan pemanfaaatan tersebut, Rigs-to-reef merupakan solusi akhir yang efektif, efesien dan ramah lingkungan dibandingkan dengan pilihan lainnya (Jagerroos \& Krause, 2016) karena pada saatnya platform tersebut harus dibongkar sesuai dengan ketentuan perundangan dan kontrak kerja antara pemerintah dan kontraktor kerjasama untuk melakukan Abandonment and Site Restoration (ASR) (Henrion et al., 2014). Terumbu buatan dikenal sebagai salah satu cara yang paling efektif untuk meningkatkan produktivitas perairan pesisir dengan menyediakan habitat tambahan bagi kehidupan laut. Struktur lepas pantai dapat menarik banyak spesies yang bermigrasi mencari makanan, tempat tinggal, dan tempat bereproduksi. Hasil pengamatan di Teluk Meksiko mengungkapkan adanya korelasi positif yang kuat antara jumlah anjungan minyak (yang dibangun sejak tahun 1950-an) dengan hasil tangkapan ikan komersial di wilayah tersebut (NOAA, 2017). Keuntungan yang didapatkan tidak hanya bagi pelaku industri ekstraktif migas seperti penghematan biaya pembongkaran (Salcido, 2005), mengurangi tanggung jawab sekaligus peningkatan citra perusahaan (Jagerroos \& Krause, 2016), akan tetapi juga bagi lingkungan pesisir dan laut dimana platform tersebut dapat dimanfaatkan untuk menciptakan habitat baru bagi ikan karang, memperbaiki lingkungan ikan karang yang rusak bahkan meningkatkan stok ikan (Cripps \& Aabel, 2002; Jagerroos \& Krause, 2016).

Penempatan struktur platform di suatu wilayah tertentu, merupakan salah satu faktor yang sangat penting untuk dipertimbangkan dalam proses rekruitment dan pembentukan karang di area baru penempatan Rigs tersebut (Sammarco, 2014). Kajian konektivitas dan proses penyebaran larva karang dan ikan dari sumber alami terdekat menentukan kesuksesan program ini (Almany et al., 2009). Pemahaman pola konektivitas pada kawasan konservasi merupakan hal yang sangat penting untuk mengetahui efektivitas kawasan konservasi perairan. Besarnya dampak dari kemampuan memperbaiki diri (resilience) dari terumbu pada kawasan konservasi tergantung pada efektifnya konektivitas antara terumbu di dalam kawasan konservasi tersebut (Underwood et al., 2009). Magris et al. (2015) menyatakan bahwa konektivitas antara kawasan konservasi tergantung pada pola dan kekuatan penyebaran larva yang berfungsi melindungi keanekaragaman hayati dan meningkatkan perikanan melalui rekruitmen yang berlangsung. Lebih jauh, Atchinson et al. (2008) menyatakan bahwa proses penyebaran dan konektivitas populasi karang akan semakin menurun dengan semakin bertambahnya jarak antara habitat baru (downstream habitat) dengan habitat asli (natural source habitat)

Konektivitas menggambarkan keragaan suatu populasi spesies yang terhubungkan satu sama lain melalui sebaran/pertukaran individu pada fase telur/ larva, juvenile dan dewasa (konektivitas populasi), bisa juga terkait dengan hubungan ekologis antar habitat yang terpisah dalam jarak. Konektivitas berkaitan dengan perpindahan organisma ikan dan material sepanjang wilayah dan berfungsi sebagai area habitat, kualitas, pengaturan dan kapabilitas penyebaran bagi spesies (Berkstrom et al. 2013). Dalam kajian ekologi spasial, konektivitas merupakan aspek kajian yang rumit karena tiap mahluk hidup memiliki lingkup ruang yang berbeda satu sama lain, untuk berinteraksi ataupun memenuhi kebutuhan hidup (Agus, 2012).

Penggunaan model biofisik telah mulai dilakukan 
untuk mempelajari konektivitas kawasan konservasi (Surbakti et al, 2014). Pemodelan biofisik dilakukan dengan memadukan antara factor biologi dan fisika untuk mendapatkan scenario rekruitmen dan jejak penyebaran larva. Pemodelan ini semakin sering digunakan sebagai alat prediksi penyebaran larva untuk menilai konektivitas antar kawasan konservasi dan untk evaluasi umum dari berbagai faktor yang berperan dalam pergerakan larva (Callwood, 2010). Model biofisik ini dapat juga digunakan untuk memperkirakan konektivitas kawasan pada skala spasial maupun temporal (Lagabrielle et al. 2014), sehingga pemanfaatan model biofisik dapat memberikan hasil yang optimal terkait dengan pemanfaatan kawasan konservasi perairan.

\section{METODE PENELITIAN}

\section{Lokasi Kajian}

Lokasi kajian berada di sekitar perairan Karang Segajah, bagian dari zona pemanfaatan dari Kawasan Konservasi Perairan Daerah (KKPD) Bontang, Kalimantan Timur (Gambar 1).

\section{Kandidat Lokasi Penempatan Struktur Platform}

Dua kandidat lokasi untuk penempatan Rigs telah ditentukan dari hasil survei lapangan dengan mempergunakan echosounder multibeam (PRK, 2017). Lokasi survey batimetri berada di perairan di sebelah barat gosong Segajah yang masuk wilayah administratif Kota Bontang Provinsi Kalimantan Timur. Lokasi yang ideal untuk penempatan Rigs adalah:

- $\quad$ Area yang luas dengan kemiringan (slope) $<10$ sehingga struktur tidak bergeser dan pindah

Kedalaman diatas $30-50 \mathrm{~m}$ (85 feet atau $26 \mathrm{~m}$ ditambah dengan lebar dari kaki Rigs jika ditidurkan/topple) untuk memastikan agar struktur yang ditempatkan tidak mengganggu alur pelayaran dan aktivitas laut lainnya (clearance)

- Jarak yang tidak terlalu jauh dari ekosistem karang sebagai sumber larva karang untuk menjamin pertumbuhan karang yang lebih baik

- Lokasi tidak memiliki kekeruhan dengan dasar perairan yang bukan lumpur dan tidak berdekatan dengan sungai sebagai sumber polutan dan sedimen.

Berdasarkan topografi dasar laut yang dihasilkan terdapat dua lokasi yang relatif datar dan dimungkinkan untuk lokasi pembuatan karang buatan, yaitu alternatif 1 (Rig-1, di posisikoordinat 0:9:14,.524U, 117:34:39,896 $\mathrm{T}$ dengan kedalaman 46,47m dan memiliki slope sekitar $0,12^{\circ}$ ) dan alternatif 2 (Rig-2, di posisi koordinat 0:10:5,005 U, bujur 117:34:53,485 T dengan kedalaman $45,30 \mathrm{~m}$ dan memiliki slope sekitar $\left.0,8^{\circ}\right)$ (Gambar 2$)$.

\section{Model Sebaran Larva}

Model sebaran larva digunakan untuk menggambarkan penyebaran larva karang di kawasan konservasi Bontang yang sampai ke lokasi kegiatan penenggelaman Rig-1 dan Rig-2. Model ini dibangun



Gambar 1. Lokasi kajian konektivitas larva karang di perairan Bontang. 


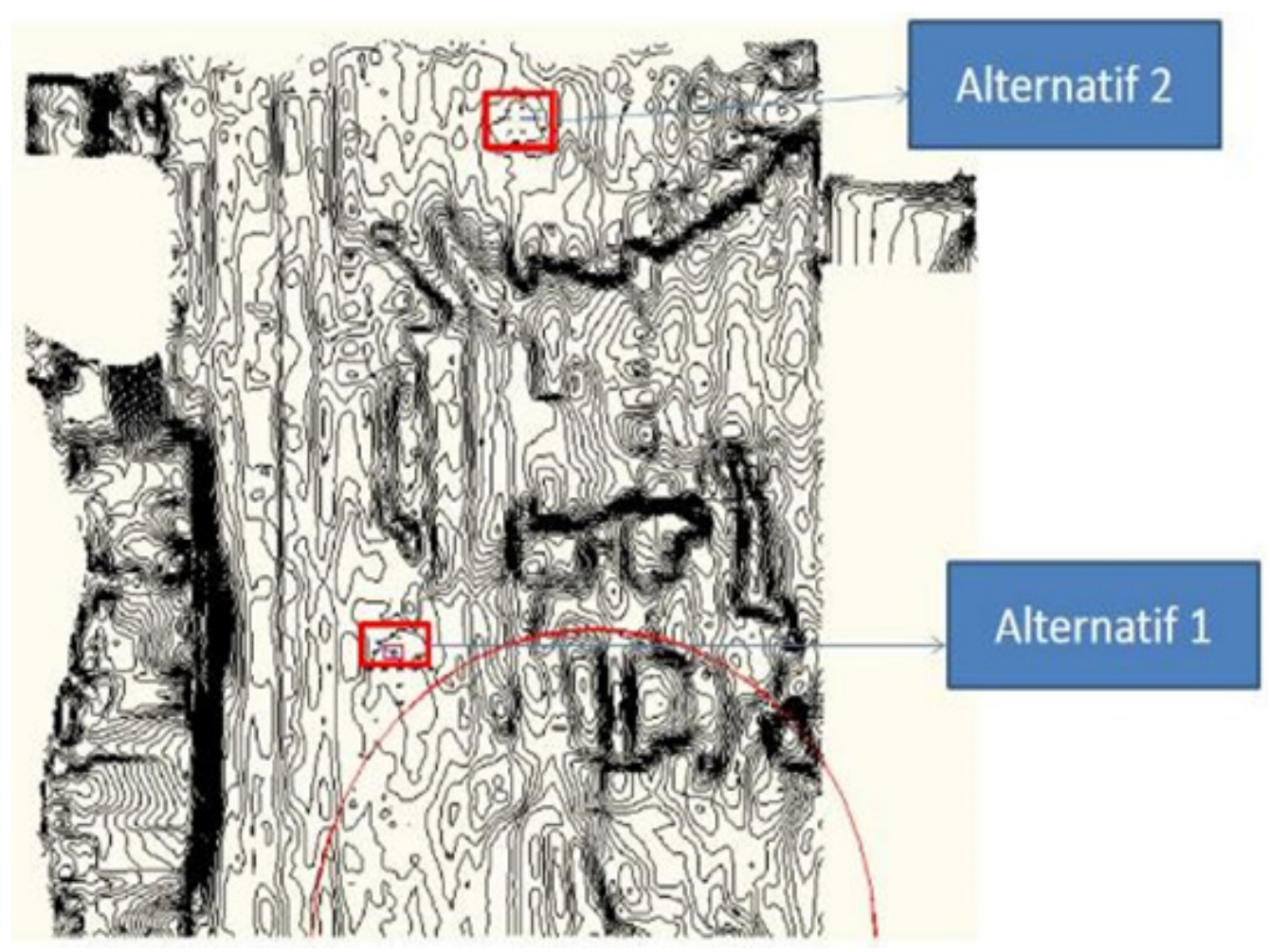

Gambar 2. Kandidat lokasi penempatan Rigs hasil survei lapangan.

menggunakan modul Eco-Lab Agent Based Modellling pada aplikasi Mike 21 Flow Model FM (DHI, 2017). Aplikasi ini menghitung perpindahan posisi larva dari input kecepatan hasil keluaran model hidrodinamika di setiap waktunya (Sufyan et al, 2017).

\section{Parameter Model Sebaran Larva}

- Dalam model pergerakan larva ini beberapa asumsi yang digunakan untuk memahami fenomena pergerakan larva adalah sebagai berikut: Sumber (source) larva ditentukan berdasarkan karakteristik kondisi karang yang baik dan sedang. Berdasarkan kondisi ini maka ditentukan 4 titik yang tersebar di kawasan konservasi sebagai lokasi sumber larva (Tabel 1).

- Densitas jumlah larva yang dilepaskan diasumsikan sama pada masing-masing lokasi sumber larva sebesar.

- Durasi waktu larva selama terbawa arus atau pelagic larval duration pada penelitian ini digunakan selama 30 hari (Kool et al, 2011; Schill et al. 2015; Treml et al. 2007).

Selama simulasi dilakukan, diasumsikan bahwa

Tabel 1.

Koordinat lokasi awal (source) larva karang

\begin{tabular}{llll}
\hline No & Lokasi & Bujur & Lintang \\
\hline 1. & Source 1 & 117,542 & 0,065 \\
2. & Source 2 & 117,561 & 0,077 \\
3. & Source 3 & 117,566 & 0,131 \\
4. & Source 4 & 117,557 & 0,154 \\
\hline
\end{tabular}

- Densitas jumlah larva yang dilepaskan diasumsikan sama pada masing-masing lokasi sumber larva sebesar -Durasi waktu larva selama terbawa arus atau pelagic larval duration pada penelitian ini digunakan selama 30 hari (Kool et al, 2011; Schill et al. 2015; Treml et al. 2007). 
tidak ada proses predasi, kematian larva dan faktorfaktor lain yang mempengaruhi durabilitas larva (Sundelof \& Jonsson, 2012).

\section{HASIL DAN PEMBAHASAN}

Proses reproduksi seksual karang umumnya terjadi pada suhu yang hangat sehingga diasumsikan terjadi sepanjang tahun untuk daerah tropis dengan waktu puncak reproduksi/spawning berbeda-beda tergantung lokasi (Manuputty, 2005; Munasik \& Widjatmoko, 2005). Berdasarkan hal tersebut maka simulasi pergerakan larva dilakukan di bulan-bulan yang mewakili 4 (empat) puncak musim yang berbeda untuk menggambarkan pola pergerakan larva yang sampai ke lokasi rencana penenggelaman Rig-1 dan Rig-2. Musim barat diwakili oleh bulan Januari, musim peralihan I diwakili bulan Mei, musim timur diwakili bulan Agustus serta musim peralihan II diwakili bulan Oktober (Mustikasari et al., 2015). Kondisi awal simulasi yang dilakukan dimana diasumsikan belum ada sumber dan pergerakan larva ditampilkan pada Gambar 3.

\section{Musim Barat}

Tipe pasang surut perairan Bontang merupakan tipe pasang surut campuran condong semidiurnal, dengan kecepatan arus rata-rata pesisir sepanjang muara $0,4-0,55 \mathrm{~m} / \mathrm{s}$ dengan kecepatan arus permukaan dekat selat Makassar mencapai $1,15 \mathrm{~m} / \mathrm{s}$ (Utami, 2016). Pergerakan larva karang yang merupakan plankton dipengaruhi terutama oleh pergerakan arus pasang surut yang merupakan arus bolak balik untuk menempel di substrat yang sesuai (Pranowo et al., 2004; Fitriadi et al., 2017; Nurulita et al, 2018). Waktu yang diperlukan planula untuk menempel di substrat yang sesuai 4- 7 hari setelah pembuahan dan dapat bertahan mencapai $26-78$ hari di perairan jika belum menemukan substrat dan kondisi lingkungan yang sesuai (Lugo-Fernandez et al., 2001; Fitriadi et al., 2017). Berdasarkan ini maka simulasi dari penelitian ini dilakukan selama 30 hari.

Hasil simulasi pergerakan larva yang dilakukan selama 30 hari pada musim barat (bulan Januari) memperlihatkan bahwa larva akan mencapai lokasi Rig-1 pada hari ke 15 . Kondisi ini akan berlangsung hingga hari ke-21 simulasi. Sedangkan pergerakan

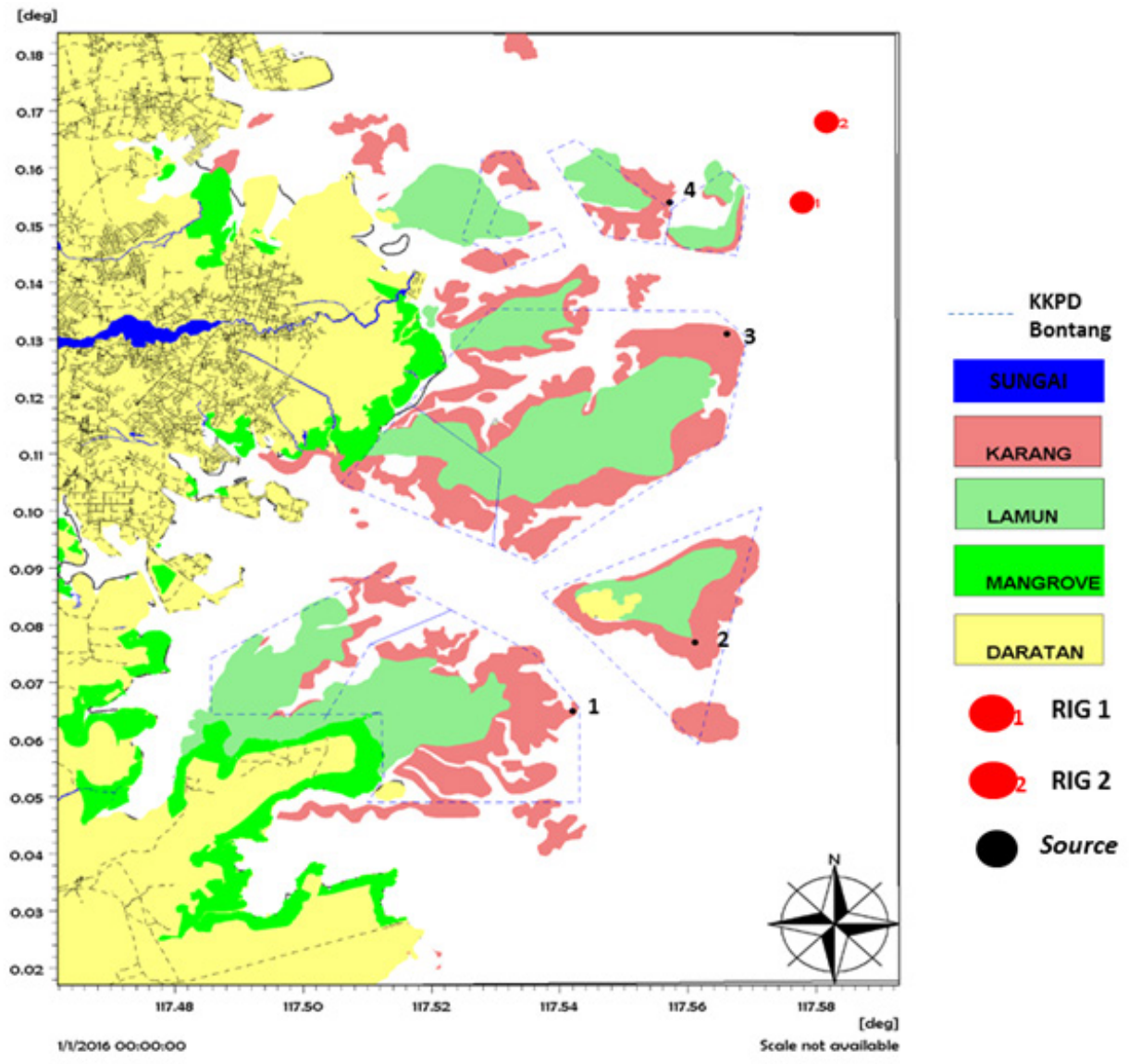

Gambar 3. Sebaran Larva Karang Pada Kondisi Awal Simulasi. 



Gambar 4. Sebaran Larva Karang Pada Saat Jumlah Larva Mencapai Kondisi Maksimum di (a) Rig-1 dan (b) Rig-2.

larva mencapai Rig-2 berlangsung pada hari ke 16. Kondisi dimana larva mencapai Rig-2 ini akan berlangsung selama 17 jam dan selanjutnya tidak ada larva yang memasuki wilayah perairan Rig-2. Larva akan memasuki perairan Rig-2 kembali pada hari ke 19. Gambaran mengenai pergerakan larva serta periode waktu yang dibutuhkan mencapai $R i g-1$ dan Rig-2 pada musim barat ditampilkan pada Gambar 4-5.
Gambar 4 memperlihatkan sumber larva karang berasal dari daerah terumbu karang di perairan KKPD Bontang (sumber 1-4). Larva karang bergerak ke arah Rig 1 dan Rig 2 diharapkan menjadi habitat penempelan larva karang pada musim barat yang cukup banyak. Berdasarkan kajian awal penempatan Rig 1 dan Rig 2 sudah sesuai untuk habitat larva karang menempel dan tumbuh sehingga akan membentuk rekruitmen karang baru.
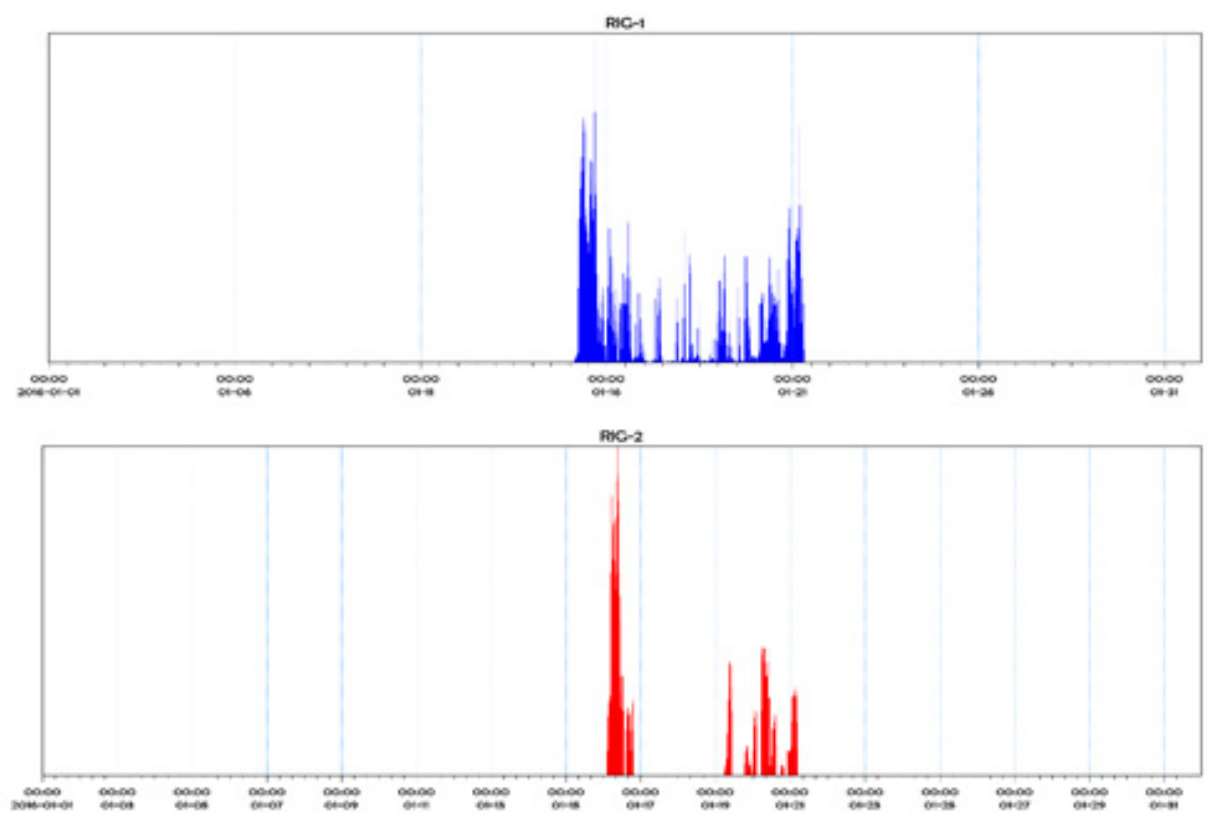

Gambar 5. Periode Sebaran Larva Karang di Rig-1 dan Rig-2. 

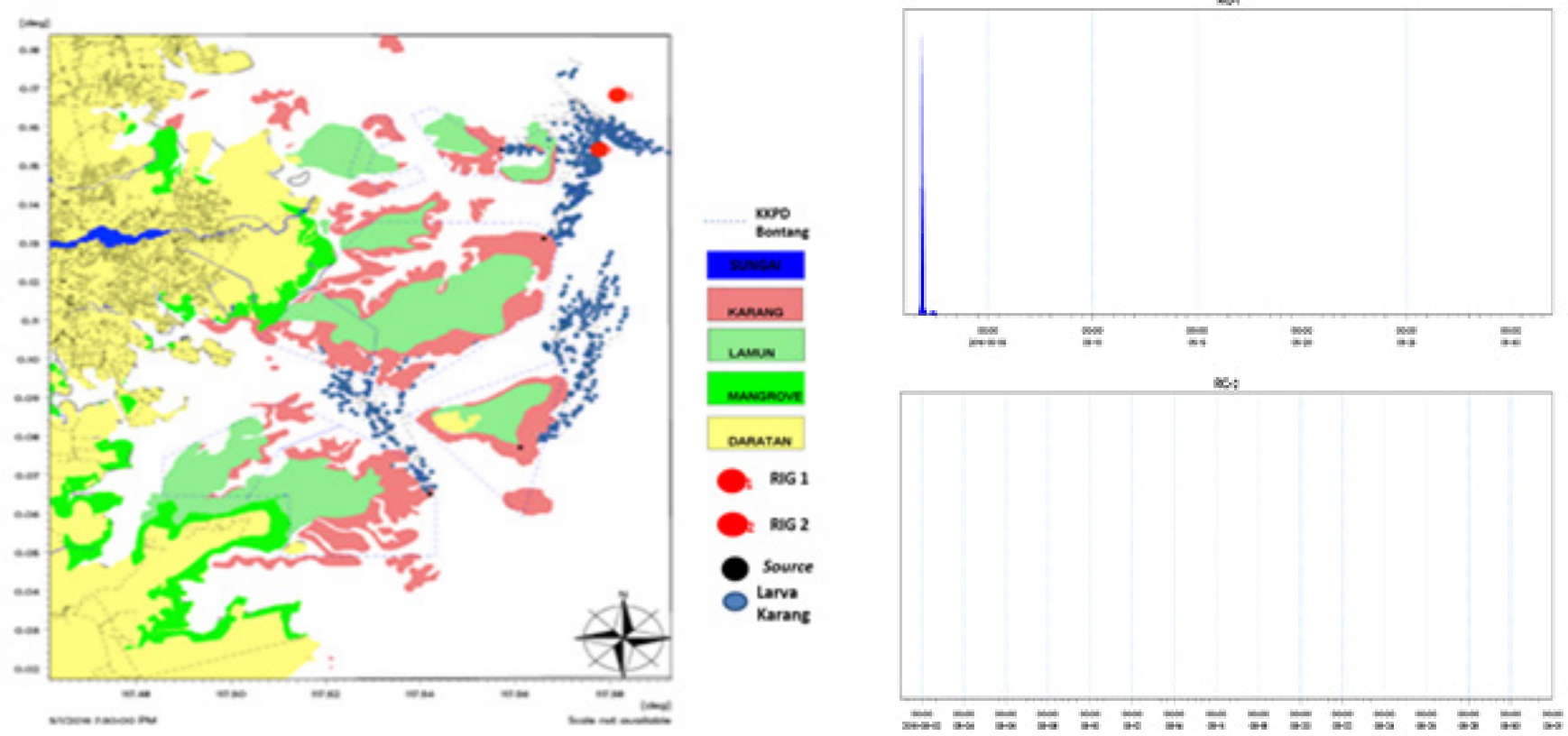

Gambar 6. Sebaran Larva Karang (kiri) Periode Sebaran Larva Karang di Rig-1 dan Rig-2 (kanan).

Gambar 5 memperlihatkan waktu hasil simulasi model mencapai lokasi Rig. Waktu tempuh larva karang yang mencapai lebih dari 15 hari pada lokasi Rig masih berpotensi larva karang menempel di Rig, sesuai dengan penelitian sebelumnya dimana pergerakan larva karang dapat mencapai 50-60 hari di perairan Florida Keys, Teluk Meksiko (Lugo- Fernandez et al, 2001).

\section{Musim Peralihan-1}

Musim peralihan-1 (Mei) memperlihatkan kondisi yang berbeda dengan musim barat. Hasil simulasi yang diperoleh menunjukkan pergerakan larva pada musim peralihan 1 (bulan Mei), tidak ditemukan pergerakan larva yang sampai ke lokasi Rig-2. Pergerakan larva yang sampai ke Rig-1 ditemukan pada hari ke 1 terutama dari lokasi sumber yang berdekatan dengan lokasi rencana pemasangan Rig yaitu Source/sumber



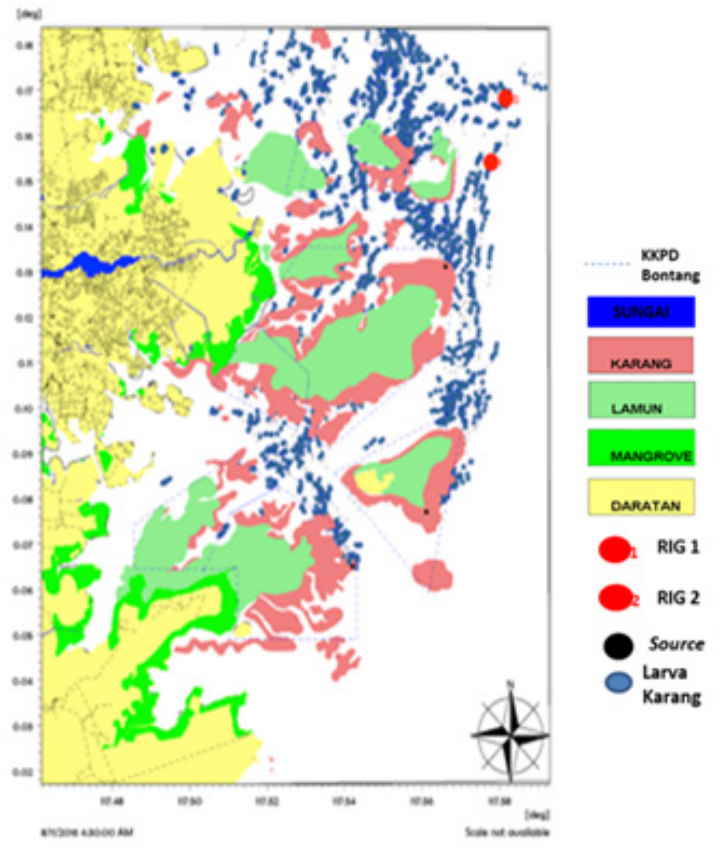

Gambar 7. Sebaran Larva Karang Pada Saat Jumlah Larva. Mencapai Kondisi Maksimum di (a) Rig-1 dan (b) Rig-2. 

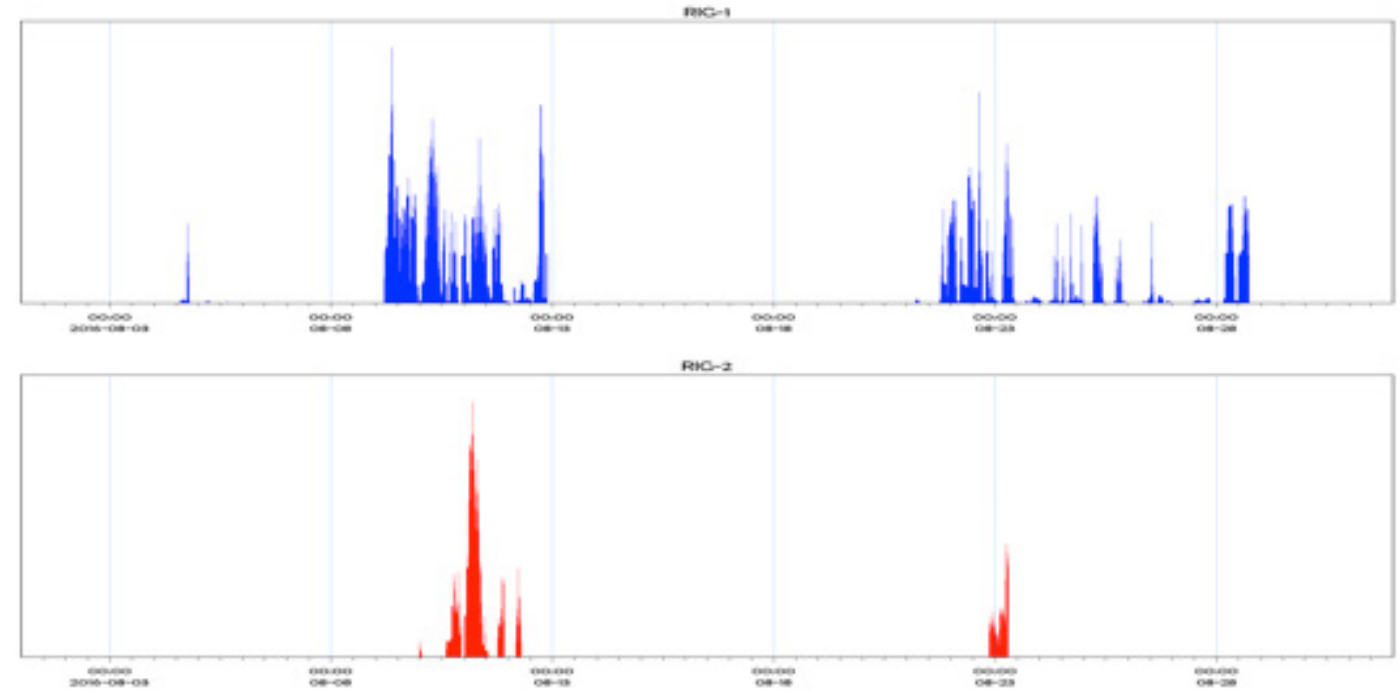

Gambar 8. Periode Sebaran Larva Karang di Rig-2 dan Rig-2.

\section{3 dan 4 (Gambar 3 dan 6 (kanan)).}

\section{Musim Timur}

Simulasi pergerakan larva yang dilakukan selama 30 hari pada musim timur (bulan Agustus) memperlihatkan bahwa pada musim ini larva akan lebih sering dijumpai memasuki perairan Rig-1 dan Rig-2. Hasil simulasi pergerakan larva menunjukkan bahwa larva akan mencapai lokasi Rig-1 pada hari ke 4 , hari ke 9 serta hari ke 21 . Sedangkan pergerakan larva mencapai Rig-2 berlangsung pada hari ke 10 dan hari ke 22. Gambaran mengenai pergerakan larva serta periode waktu yang dibutuhkan mencapai Rig-1 dan Rig-2 pada musim barat ditampilkan pada Gambar 7-8.

\section{Musim Peralihan-2}

Kondisi yang yang sama dengan musim peralihan I diperoleh dari hasil simulasi pergerakan larva pada musim peralihan II (bulan Oktober). Pada bulan Oktober juga tidak ditemukan pergerakan larva yang sampai ke lokasi Rig-2. Sedangkan pergerakan larva yang sampai ke Rig-1 ditemukan pada hari ke-1 terutama dari lokasi sumber yang berdekatan dengan lokasi rencana pemasangan Rig. Kondisi ini akan kembali dijumpai pada hari ke-7 simulasi dan setelah itu hampir dijumpai lagi kondisi dimana larva akan sampai ke lokasi tersebut. Gambaran mengenai pergerakan larva serta periode waktu yang dibutuhkan mencapai Rig-1 pada musim peralihan II ditampilkan pada Gambar 9.

Hasil pemodelan sebaran larva karang dari kawasan konservasi Bontang menunjukkan konektivitas antar lokasi asal larva dengan lokasi penempatan Rigs. Peluang terbesar penempelan larva karang dan rekruitmen karang untuk pembentukan artificial reef dari Rig lebih besar di Rig 1 dibandingkan
Rig 2 berdasarkan simulasi model. Hal ini dilihat dari peluang sepanjang tahun dari empat musim terdapat larva karang di sekitar lokasi Rig 1. Lokasi Rig 2 pada musim peralihan tidak terlihat adanya larva karang di lokasi sekitarnya. Hal ini dapat disebabkan pergerakan dan sumber larva untuk Rig 2 hanya dari source 3 dan 4 dengan asumsi larva karang dapat mencapai lokasi Rig2 dalam keadaan hidup, sedangkan source 1 - 4 berpeluang lebih besar dapat mencapai Rig1 dalam keadaan hidup. Namun keberlangsungan artificial reef dari Rig terutama di lokasi Rig 2 dapat ditunjang dengan melakukan transplantasi karang, sehingga bibit tidak hanya diharapkan berasal alami dari larva karang hasil pemijahan juga melakukan reproduksi vegetatif terumbu karang dengan transplantasi dan pemasangan arus listrik lemah mengakresi mineral terutama kalsium karbonat untuk mempercepat proses pertumbuhan karang transplantasi yang dikenal dengan metode biorock dengan memanfaatkn listrik tenaga surya (Maduppa et al, 2007; Ndahawali, 2016).

Diketahuinya pola pergerakan larva dan tingkat konektivitas antar habitat dapat dijadikan landasan untuk mengajukan lokasi tersebut kepada pemangku wilayah (pemda Provinsi Kalimantan Timur dan Kota Bontang) untuk mengalokasikan daerah tersebut sebagai lokasi ideal untuk penempatan R2R dan diusulkan dalam rencana zonasi wilayah pengelolaan pesisir (RZWPP) Kalimantan TImur.

\section{KESIMPULAN}

Hasil simulasi menunjukkan bahwa proses penyebaran dan pergerakan larva karang yang bersumber dari kawasan konservasi Bontang sangat dipengaruhi oleh pola arus yang dibangkitkan oleh pasang surut dan variasi musiman angin (monsoonal pattern). Berdasarkan hasil simulasi yang dilakukan 



Gambar 9. Sebaran Larva Karang (kiri) Periode Sebaran Larva Karang di Rig-1 dan Rig-2 (kanan).

juga diperoleh gambaran bahwa terdapat perbedaan pola sebaran larva pada masing-masing musim terutama terkait dengan distribusinya terhadap rencana di lokasi Rig-1 dan Rig-2. Pada periode musim barat dan musim timur, pergerakan larva dari keempat lokasi sumber yang diberikan dapat mencapai lokasi penenggelaman Rig-1 dan Rig-2, sedangkan pada kondisi musim peralihan I dan musim peralihan II, pergerakan larva hanya mencapai lokasi Rig1 dan hampir tidak ditemukan pergerakan larva yang mencapai Rig-2. Diperlukan penelitian lebih lanjut terkait dengan keberadaan terumbu karang di lokasi KKPD Bontang meliputi keanekaragaman hayati juga potensi sebagai donor untuk transpalantasi di Rig 1 dan Rig 2. Hal ini berguna mempercepat pemanfaatan Rig 1 dan Rig 2 sebagai artificial reef yang baru selain mengandalkan penempelan alami dari sebaran larva karang yang terbawa dan menempel di struktur Rig.

\section{PERSANTUNAN}

Penelitian ini merupakan implementasi kerjasama antara Indonesia (Pusat Riset Kelautan, BRSDMKP KKP) dan Korea (KMOUC) yang dibiayai oleh APBN DIPA TA 2018. Lisensi Software MIKE21 adalah Pusat Riset Kelautan Badan Riset dan SDM KKP. Kontributor utama tulisan ini adalah R. Bambang A Nugraha dan Heron Surbakti.

\section{DAFTAR PUSTAKA}

Agus, S.B. (2012). Kajian konektivitas habitat ikan terumbu ontogeny menggunakan pemodelan geospasial di perairan Kepulauan Seribu.

\section{Disertasi. Institut Pertanian Bogor}

Almany, G.R., Hogan, D., Connolly, S.R., Heath, D.D., . McCook, L.J., Mills, M., Williamson, D.H., Pressey, R.L., \& Jones, G.P. (2009). Connectivity, biodiversity conservation and the design of marine reserve networks for coral reefs. Springer. Coral Reefs (2009) 28:339-351 DOI 10.1007/s00338009-0484-x;

Atchinson, A.D., Sammarco, P.W., \& Brazeau, D.A . (2008), Genetic connectivity in corals on the flower garden banks and surrounding oil/gas platforms, Gulf of Mexico. J Exp Mar Biol Ecol, 365: 1-12.

Bemment, R. (2001). Decommissioning Topic Strategy. Offshore Technology report. Bomel. Ltd. ISBN 0 717620549.

Bergstrom, L., Sundqvist, F., \& Bergstrom, U. (2013). Effects of an " offshore wind farm on temporal and spatial patterns in the demersal fish community Mar. Ecol. Prog. Ser. 485 199-210.

Calwood, K.A. (2010). Use of Larval Connectivity Modeling to Determine Settlement Habitats of Panulirus argus in The Bahamas as a Pre-cursor to Marine Protected Area Network Planning. Dissertation. Univerisity of Miami. Open Access Theses. 59. https://scholarlyrepository.miami.edu/ oa_theses/59;

Cripps, S.J., \& Aabel, J.P. (2002). Environmental and Socio-economic Impact Assessment of Ekoreef, 
a Multiple Platform Rigs-to-Reefs Development. ICES Journal of Marine Science, 59: S300-S308. 2002 doi:10.1006/jmsc.2002.1293

\section{DHI. (2017). MIKE 21 \& MIKE 3 Flow Model FM ABM} Lab Module Short description $10 \mathrm{pp}$.

Henrion, M., Bernstein, B., \& Swamy, S. (2014). A Multiattribute Decision Analysis for Decommissioning Offshore Oil and Gas Platforms. International Environmental Assessment and Management Journal (IEAM).

Jagerroos, S., \& Krause, P.R. (2016). Rigs-to-reef: Impact or Enhancement on Marine Biodiversity. Journal of Ecosystem and Ecography. 6(2). ISSN:2157-7625 JEE, an open access journal. DOI: 10.4172/2157-7625.1000187;

Kolian, S., \& Sammarco, P.W. (2005). Mariculture and Other Uses for Offshore Oil and Gas Platforms: Rationale for Retaining Infrsatructure: technical report. Eco-Rigs of Eco-Endurance Center Baton Rouge Lousiana-USA;

Kool, J.T., Paris, C.B., Barber, P.H., \& Cowen, R.K., (2011). Connectivity and the development of population genetic structure in Indo-West Pacific coral reef communities. Glob. Ecol. Biogeogr. 20, 695-706;

Lagabrielle, E., Crochelet, E., Andrello, M., Schill, S., Arnaud-Haond, S., Alloncle, N., \& Ponge, B. (2014). Connecting MPAs -Eight challenges for science and management. Aquatic Conservation: Marine and Freshwater Ecosystems, 24(2), 94110.

Lugo-Fernandez, A., Deslarzesa, K.J.P., Price, J.M., Bolanda, G.S., Morin, M.V. (2001). Inferring probable dispersal of Flower Garden Banks coral larvae (Gulf of Mexico) using observed and simulated drifter trajectories. Cont Shelf Res, 21, 47-67.

Madduppa, H.H., Subhan, B., Bachtiar, R., Ismet, M.S., Budikartini, Y., \& Bria, D. (2007). Prospek Terumbu Buatan Biorock Dalam Peningkatan Sumberdaya Ikan Di Kepulauan Seribu. Prosiding Munas Terumbu Karang.

Magris, R. A., E. A. Treml, R. L. Pressey, and R. Weeks. (2015). Integrating multiple species connectivity and habitat quality into conservation planning for coral reefs. Ecography, 38, 1-16.

Manuputty, A.E.W. (2005). Reproduksi Dan Propagasi Pada Octocorallia. Oseana, 30(1), 21-27. ISSN
0216-1877

Munasik. \& Widjatmoko, W. (2005). Reproduksi Karang Acropora aspera di Pulau Panjang, Jawa Tengah : II. Waktu Spawning. J. IImu Kelautan. 10(1), 30 -34 ISSN 0853 - 7291

Mustikasari, E., Dewi, L.C., Heriati, A., \& Pranowo, W.S. (2015). Pemodelan Pola Arus Barotropik Musiman 3 Dimensi (3D) Untuk Mensimulasikan Fenomena Upwelling di Perairan Indonesia. J. Segara, 11(1), 25-35.

National Oceanic and Atmospheric Administration (NOAA), (2017a). Decommissioning and Rigs to Reefs in the Gulf of Mexico: Frequently Asked Questions. Available at: http://sero.nmfs. noaa.gov/habitat_conservation/documents/gulf_ decommissioning_and_Rigs_to_reefs_faqs_final. pdf.

Ndahawali, D.H., Hamel, S., Barokah., \& Ticoalu, D. (2016). Rancang Bangun Struktur Biorock Dengan Sumber Energi Tenaga Surya. Buletin Matric, 13(1), 3-11.

Salcido, R.E. (2005). Enduring Optimism: Examining the Rigs-to-Reef Bargain. McGeorge School of Law Scholarly Articles. University of the Pacific Scholarly Commons.

Sammarco, P. (2014). Coral Community Development on Offshore Platforms in the Gulf of Mexico: What We Now Know. Book. Interrelationships Between Corals and Fisheries. Chapter Seven. P.113-126. DOI: 10.1201/b17159-8. file://I Users/badhityan/Downloads/SammarcoPlatformCoralFishChap-1.pdf

Schill, S.R., Raber, G.T., Roberts, J.J., Treml, E.A., Brenner, J., \& Halpin, P.N. (2015). No reef is an island: Integrating coral reef connectivity data into the design of regional-scale marine protected area networks. PLoS One, 10, 1-24;

Sufyan, A., Akhwady, R., Risandi, J., \& Syadiah, N. (2017). Analisa Hidro Oseanografi Pulau Liwungan Untuk Studi Kelayakan Struktur Dermaga Apung. Jurnal Kelautan Nasional, 12(3), 127-139

Sundelöf, A., \& Jonsson, P.R. (2012). Larval dispersal and vertical migration behaviour - a simulation study for short dispersal times. Mar. Ecol. 33, 183-193.

Surbakti, H., Agus, S.B., Sunuddin, A. (2014). Dinamika Oseanografi Sebagai Komponen Kunci dalam 
Menyusun Strategi Konservasi untuk Rumusan Pengelolaan Berbasis Ekosistem. In: Mini Simposium Pengelolaan Kawasan Konservasi Untuk Perikanan Berkelanjutan; Side Event Konferensi Kelautan Nasional (KONAS) IX, Surabaya.

Treml, E.A., Halpin, P.N., Urban, D.L., \& Pratson, L.F., (2008). Modeling population connectivity by ocean currents, a graph-theoretic approach for marine conservation. Landsc. Ecol. 23, 19-36;

Underwood, J.N. (2009). Genetic Diversity and Divergence among Coastal and Offshore Reefs in Hard Coral Depend on Geographic Discontinuity and Oceanic Currents. Evolutionary Applications. ISSN 1752-4571

Utami, U. (2016). Perencanaan Dermaga Island Berth Untuk Kapal Tanker 85.000 Dwt Untuk Loading Oil Product : Bbm Ron 85 Di Tersus Pt Badak Ngl, Bontang. TA Skripsi ITS. Surabaya.

\#Nurulita V K, Purba N P, Mulyani Y, Harahap S A. 2018. Pergerakan Larva Karang (Planula) Acropora di Kepulauan Seribu, Biawak dan Karimunjawa Berdasarkan Kondisi Oseanografi. Jurnal Perikanan dan Kelautan. Vol IX No2. 16 - 26

\# Fitriadi, C.A., Dhahiyat, Y., Purba, N.P., Harahap, S.A., Prihadi, D.J. 2017. Coral larvae spreading based on oceanographic condition in Biawak Islands, West Java, Indonesia. BIODIVERSITAS. Vol 18 No 2: 681-688. DOI: 10.13057/biodiv/d180234

\#Pranowo, W.S., Yulia Herdiani, \& Ivonne M. Radjawane.: Barotropic Tidal and Wind-Driven Larval Transport on Saleh Bay, Sumbawa, Indonesia. Proceeding The Twelfth OMISAR Workshop on Ocean Models (WOM-12), 7-10 September, 2004. Dalian, P. R. China. page: p.12 
Model Numerik Lintasan Sebaran Migas ...... Lepas Pantai (Rig To Reef) (Nugraha, R.B.A., et al.) 